\title{
Notes on Cribraria minutissima and Licea minima.
}

\author{
GEORGE A. REX.
}

\section{Cribraria minutissima Schwz.}

There is a marked discrepancy between the original description of this species by Schweinitz ${ }^{1}$ drawn from the type specimens now in the Schweinitzian herbarium in the Academy of Natural Sciences of Philadelphia, and the later descriptions of Rostafinski and Massee which were drawn from the Schweinitzian specimens in the Berkeleyan herbarium.

The two specimens apparently differ in important points. The diagnostic description of Schweinitz, however, accurately describes the curiously shaped elongated sporangia of the type, which appear as if ellipsoidal when first developed, becoming finally constricted in the middle when mature. The sporangia have the appearance of being girt by a thread, expanding above and below into two nearly equal globose portions, the diameter at the central constriction being from onehalf to three-fourths the diameter of the upper and lower portions. A longitudinal section through the center of a typical sporangium suggests the outline of the figure $\mathbf{8}$, as was aptly stated by Schweinitz in his description.

Below the constriction, the sporangial wall forms a permanent calyculus, but above, it expands into a globose network of band-like threads only occasionally wider at the intersections, and forming irregular meshes.

The Berkeleyan specimen, on the contrary, is described as having no permanent wall or calyculus, but simply a permanent globose network of the same character as that of the typical specimen.

The marked central constriction found in the type specimens is not, however, a fixed character, according to the observations of the writer, who has seen associated both constricted and unconstricted ellipsoidal sporangia, the latter approaching very closely the obovate sporangia of Cribraria microscopica
B. C.

An important point necessary to be considered in this con-

\footnotetext{
${ }^{1}$ De Schweinitz, L. D., Synopsis Fungorum in America Boreali media degen-

tium. Proc. Am. Philos. Soc. 1831. [Philadelphia.]
} 
nection is the relation of $C$ : microscopica B. \& C. to the two foregoing Schweinitzian forms. In their spores and network these three forms essentially agree. They vary only in the shape of the sporangium, which is a diagnostic character of no specific value, and in the size or degree of development of the calyculus which must be conceded to be variable and therefore a specific character of doubtful value.

The only species of Cribraria created solely upon the absence of a calyculus as a determining specific factor is $C$. dictydioides Balf.; but the great variability in the size of the calyculus in different gatherings and even in the same gathering of the allied and overlapping species $C$. tenella and $C$. intricata makes the validity of $C$. dictydioides more than doubtful.

Sporangia without calyculi associated with others having minute disciform calyculi are constantly found with the typical net characters of both the above species. The same variability of the calyculus is also found, though to a much less extent, in sporangia of the type of $C$. vulgaris Schrad.

As C. microscopica B. \& C. differs from typical C. minutissima Swz. only in having globose or slightly obovate instead of ellipsoidal sporangia, the writer concludes that it is not specifically distinct, but should be merged in $C$. minutissima Swz. which is the older species.

The Berkeleyan form of $C$. minutissima Swz. holds the same relative position to the type as $C$. dictydioides to $C$. intricata and $C$. tenella. It is a constant variety of $C$. minutissima and could only doubtfully be assigned a separate and valid specific place.

The localities for this species known to the writer are Fairmount Park, Phila.; Shawangunk Mts., N. Y.; Newfield, N. J. (J. B. Ellis); and the original station at Bethlehem, Penn. (Schweinitz). The Berkeleyan variety is probably more frequently found than the typical form.

In the preparation of the preceding notes the writer examined and compared the type of $C$. minutissima Swz. in the Schweinitzian herbarium, with an authentic specimen of C. microscopica B. \& C. communicated by Dr. Curtis, the collector and one of the authors of the type, to the herbarium of the Academy of Natural Sciences, Philadelphia, which corresponds absolutely to the descriptions of the type by Rostafinski and Massee and is probably a part of the same gathering. Specimens from several private collections, illustrating the Berkeleyan variety, were also examined. 


\section{Licea minima Fr.}

This obscure and little known species has an interesting developmental history.

The sporangia of the American, like those of the European specimens, vary in color greatly. All, except one, of several gatherings from various American localities examined by the writer were of various shades of chestnut or umber brown. In the exception, the color of the sporangial wall was dull black by reflected light, but dark reddish brown or black by transmitted light.

The upper surface of the sporangia in all of the gatherings, was divided by seams or ridges into from four to six parts. In the brown specimens these seams were of a darker brown than the adjacent parts, but in the black specimens they were jet black, smooth and shining. They extend from the base to the center of the surface of the sporangia when of the usual depressed hemispherical form, but to a short central or apical ridge when the sporangia are elongated. These ridges are sutural in character and mark the lines of the rupture of the sporangia upon the dispersion of the spores. The rupture takes place through the middle of the sutures and the resulting segments of the sporangial wall become partly reflexed, thus giving a serrated margin to the cup-like sporangial cavity left by the scattered spores.

The location of these sutures is indicated early in the development and differentiation of the sporangia from the plasmodium.

This fact the writer was able to verify while observing the very interesting development of the sporangia of the black form.

When found, the plasmodium had just entered the first stage of differentiation and had formed cushion-shaped masses of a uniform dull yellow color, probably two and three times the diameter of the mature sporangia. As the development and maturation advanced, the plasmodic masses diminished correspondingly in size, and in the smooth yellow plasmodium the sutures characterizing the mature sporangia began to differentiate, first as double rows of minute dark garnet colored pigment points which gradually grew larger and darker and finally blended, forming black shiny sutures at maturity. While the sutures were developing, the whole sporangial surface also changed from yellow to dark garnet, and finally 
black, the pigmentation commencing at the sutural and basal lines and spreading thence toward the centers of the segments of the sporangial wall. The lines of rupture occurred between the rows of pigment points which first outlined the sutures. On examination of the matured sporangial wall under proper microscopical conditions of light and high amplification, a marginal line of rounded cells, varying in degree in different specimens, may usually be seen following the outline of the segments and marking the position of the primary sutural points or foci of pigmentation.

This species will probably be found to be as widely distributed in the northern United States as in northern Europe, where only it has yet been recorded. It was recorded by Schweinitz in his herbarium and in his synopsis of North American fungi under the name of Licea pusilla Schrad., with which species it is probably often confounded.

The writer is indebted to the courtesy of Arthur Lister, Esq., of London, for the identification of his specimens with authentic specimens of the species.

The American localities for this species, known to the writer, are Philadelphia, Pa.; Adirondack Mts., N. Y.; and Newfield, N. J. (J. B. Ellis).

Philadelphia, Pa. 


\section{$2 \mathrm{BHL}$ Biodiversity Heritage Library}

Rex, George A . 1894. "Notes on Cribraria minutissima and Licea minima." Botanical gazette 19(10), 397-400. https://doi.org/10.1086/327101.

View This Item Online: https://www.biodiversitylibrary.org/item/93164

DOI: https://doi.org/10.1086/327101

Permalink: https://www.biodiversitylibrary.org/partpdf/222405

\section{Holding Institution}

Missouri Botanical Garden, Peter H. Raven Library

\section{Sponsored by}

Missouri Botanical Garden

\section{Copyright \& Reuse}

Copyright Status: Public domain. The BHL considers that this work is no longer under copyright protection.

This document was created from content at the Biodiversity Heritage Library, the world's largest open access digital library for biodiversity literature and archives. Visit BHL at https://www.biodiversitylibrary.org. 